\title{
Integrated Coastal Zone Management: Ecological, Socio- Economic and Governance Challenges
}

\section{Roshan T Ramessur}

Faculty of Science, University of Mauritius, Reduit, Mauritius

*Corresponding author: Roshan T Ramessur, Faculty of Science, University of Mauritius, Reduit, Mauritius, Tel: +230 4037511 ; Fax: +230 465 6928 ; E-mail: ramessur@uom.ac.mu

Received date: April 14, 2015, Accepted date: April 16, 2015, Published date: April 25, 2015

Copyright: $\odot 2015$ Roshan TR. This is an open-access article distributed under the terms of the Creative Commons Attribution License, which permits unrestricted use, distribution, and reproduction in any medium, provided the original author and source are credited.

\section{Editorial}

In the past 35 years, ICZM has become recognized as fundamental to good management of coastal resources as the World Bank, United Nations Environment Programme, United Nations Development Programme and the Food \& Agriculture Organization recognize the special importance of coastal areas and resources, and are all involved in promoting, developing or implementing ICZM programmes worldwide and encouraging the use of ICZM indicators [1-3]. The development of an integrated coastal management framework for Mauritius is promoting sustainable development in the coastal zone and has moved towards optimisation of long-term socio-economic and environmental benefits [4-7]. The ICZM remains a continuous, proactive and adaptive process of resource management of multisectoral activities and maintains options for future uses of coastal and ocean resources in islands of the South West Indian Ocean and mainland coastal East Africa. The approach adopted under Recomap in 2008 has been one which examine many solutions and approaches, optimising strategies, plans and policy formulation. Final suggestions thereby representing best practices stand the best chance of adoption and success during implementation and it is essential to ensure stakeholder ownership of the programme achieved through stakeholder participation across the region. The approach is process oriented inclusive and has aimed to build consensus focusing on what is practical and achievable within the parameters of the programme, given the resource constraints, institutional capacity and willingness of other institutions and agencies, and other stakeholders to participate. Institutional integration and cooperation and stakeholder participation are not easily achieved, especially in the initial stages of the process and ICZM is considered a long-term process and strategy which gradually encourages, the major players and key stakeholders to join whenever they feel it is appropriate to do so [8-10]. A necessary condition for cooperation among different institutions is agreement on overall goals or strategic objectives, in resolving particular issues as the holding of regular meetings of the National ICZM Committee. The key to the beginning of cooperation is therefore an agreement on a tangible strategic objective that is of benefit to all concerned. Equally important, for the successful coordination and cooperation, is the development and establishment of an organisational structure that ensures maintenance of communications among organisations, provides effective oversight and handles disputes [11-13]. The ICZM project has been to prepare an ICZM strategy for Mauritius in line with government policies and strategies for overall sustainable development and also in accordance with the requirements of various regional and multi-lateral agreements to which Mauritius is party and which are pertinent to ICZM; to review and develop an appropriate policy and regulatory framework that promotes ICZM; and to develop ICZM plans for pressure zones to guide future development and interventions to promote sustainable development in the CZ [14-20]. In line with WIOMSA 2015 symposium in Durban, South Africa and COP21, Paris 2015, Mauritius is undertaking measures for sustainability, climate change adaptation and disaster mitigation towards the increase of renewable energy sources as discussed in RESUS 15 in Mauritius which would be beneficial to the island [21-25]. Articles and reviews aimed at increasing effective coastal zone management in ocean states are encouraged under the DPSIR Framework adopted for Integrated Coastal and Ocean Management so as to maximise the economic and social benefits obtained from the coastal region over the long term as holistic management of the often conflicting pressures on the coastal zone is essential [26-34].

\section{References:}

1. Ramessur RT, Parry SJ, Ramjeawon T (2001) The relationship of dissolved $\mathrm{Pb}$ to some dissolved trace metals $(\mathrm{Al}, \mathrm{Cr}, \mathrm{Mn}$ and $\mathrm{Zn}$ ) and to dissolved nitrate and phosphate in a freshwater aquatic system in Mauritius. Environment International 26: 223-230.

2. Ramessur RT, Daby D, Marie D (2001) Challenges of exploiting the ocean resources in the EEZ around Mauritius. Online Mermaid Proceedings.

3. Ramessur RT (2002) Ocean Resource Exploitation of a Small Island State in the South Western Indian Ocean. PIM 2002 Workshop. Cape Town.

4. Ramessur RT (2002) Anthropogenic driven changes with focus to the coastal zone of Mauritius, South Western Indian Ocean. Regional Environmental Change 3: 99-106.

5. Ramessur RT, Fagoonee I (1999) Integrated Coastal Zone Management, Mauritius. Proceedings of the S. Asia regional workshop on estuarine Modelling and coastal zone management, START/LOICZ/IGBP-SL. 43-53.

6. Ramessur RT, Parry SJ, Jarvis KE (1998) Characterization of some trace metals from the Export Processing Zone and a coastal tourist area in Mauritius using ICP-MS. Environment International 24: 773-781.

7. Ramessur RT (2009) Networked Learning for an Online ICZM module. Proceedings 20th ICCE - In: Chemistry in the ICT Age 101-106

8. Swayne D, Denko M, Fagoonee I, Marshall L, Ramessur RT, et al. (2007) ICT Issues for Environmental monitoring and management. Environment. IFIP WITFOR 2007 (World Information Technology Forum). IFIP Press Austria. 97-110

9. Ramessur RT, Santally MI (2007) Computer mediated communication for effective teaching-learning of coastal zone management module. International Journal of Education and Development 3: 116-125

10. Ramessur RT, Parry SJ (1998) Variation of major elements and nutrients in a coastal system in Mauritius. University of Mauritius Research Journal 2; 145-157.

11. Ramessur RT (1997) Assessment of a tropical lagoon in Mauritius using semi-quantitative techniques. Rev Agri et Suc 76: 26-30.

12. Ramessur RT (1996) The use of a GIS for the coastal zone management of a seaside resort area in Mauritius PROSI 324: 20-25.

13. Ramessur RT (1991) Coral zonation at Flic en Flac, University of Mauritius Research Journal 3-11 
14. Ramessur RT (2014) Sustainable Development: The Need for Vulnerability Resilience Profile and the Green Economy Transition in Mauritius. J Geogr Nat Disast 4: 116

15. Ramessur RT (2013) A Review of Coastal Zone Management Facing Climate Change and Natural Disasters in Mauritius. J Geogr Nat Disast 1: 3

16. Ramessur RT (2013) Coastal Zone Facing Climate Change: Knowledge Towards New Solutions. J Coast zone management 16: e103.

17. Ramessur RT (2013) Coastal Morphodynamics and Human Impacts. J Coast zone management 16: 104.

18. Boodhoo K, Ramessur RT. Exploration and Potential Exploitation of Deep Sea Minerals in the EEZ and ECS of Mauritius. Proceedings International Workshop on Minerals Processing and Beneficiation, Johannesburg, South Africa, In: Al Otoom, A and Al-Harahsheh, M Editors NAMST Astral International PVT Ltd 227-240

19. Ramessur RT, Boodhoo K (2013) Trace Metal Contamination in Urban Sediments in Port Louis, Mauritius. Ecology and Environment Research 1; $155-160$

20. Ramessur RT, Boodhoo K, Balgobin J, Povinec P, Burnett WC (2012) Dissolved nutrients in submarine groundwater discharge in Flic en Flac lagoon, Mauritius. Sixth Wiomsa Symposium. Western Indian Ocean Journal of Marine Science 10; 121-127

21. Povinec PP, Burnett WC, Beck A, Bokuniewicz H, Charette M, et al. (2012) Isotopic, geophysical and biogeochemical investigation of submarine groundwater discharge: IAEA-UNESCO intercomparison exercise at Mauritius Island. Journal of Environmental Radioactivity 104; 24-45

22. Bissembur ZB, Balgobin J, Anjore A, Ramessur RT, Boodhoo K (2011) Investigation of Dissolved Nutrients in Tropical Coastal Waters in Mauritius. ICPAC Conference 1-10

23. Unauth P, Ramessur RT, Boodhoo K (2011) A study about perception of coastal zone management issues related to climate change in Mauritius. In: Water and Pollution Management Chapter 7; 96-115.

24. Ramessur S, Ramessur RT, Boodhoo K (2011) A capability approach of health poverty implications following non point water pollution: The case of Grand River North West in Mauritius. 25. In: Water and Pollution Management 17; 227-245. Biotech Books
25. Ramessur RT, Boodhoo K, Bissembur ZB, Balgobin J, Boyjoo A (2011) Investigation of lead and zinc in coastal sediments from the north west of Mauritius. J Env Research and Development. 5; 516-523

26. Jowaheer V, Lalbahadoor V, Ramessur R, Dosoruth L (2010) A multifactor statistical model for analyzing the physic-chemical variables in the coastal area at St Louis and Tamarin, Mauritius. Journal of Applied Quantitative Methods. 5; 89-97

27. Burnett WC, Aggarwal PK, Bokuniewicz H, Cable JE, Ramessur RT, et al. (2006). Quantifying Submarine Groundwater Discharge in the Coastal Zone via Multiple Methods. Science of the Total Environment. 367; 498-543.

28. Ramessur RT, Santally MI (2005) Asynchronous Computer Mediated Conferencing for an online ICZM Module. 2nd ICOOL Proceedings. WCCE.

29. Ramessur RT, Daby D (2003) Effects of anthropogenic and natural impacts on coral reef management in Mauritius. Proceedings of the International Coral Reef Initiative (ICRI) regional workshop for the Indian Ocean 113-27.

30. Ramessur RT, Santally MI (2003) Design and online delivery of a coastal zone management module using a constructivist approach. 1st ICOOL Proceedings.

31. Ramessur RT, Khurun P (2003). Trace metal levels from estuarine sediments in Mauritius. Journal de La Nature. 15; 5-9.

32. Ramessur RT, Ramjeawon $\mathrm{T}$ (2002) Determination of $\mathrm{Pb}, \mathrm{Cr}$ and $\mathrm{Zn}$ from an urbanized river in Mauritius. Environment International 28; 315-324.

33. Lollchund MR, Dilmahamod F, Boodhoo K, Ramessur RT (2015) Correlations between monthly precipitation, SST, humidity and CO2 levels in the tropical South West Indian Ocean (SWIO) basin. RESUS 15 Proceedings.

34. Ramessur RT, Gunputh RP, Ramessur TS (2013) Climate Compatible Development: Legal Implications in the Coastal Zone and Inclusive Development for Mauritius. J Coastal Zone Management 16: 378 